\title{
Symbolic Learning through Information and Communication Technology in Pakistani Universities: Prospects and Possibilities
}

\author{
Muhammad Mushtaq \\ PhD Scholar, Department of Education, Faculty of Social Sciences, International Islamic University, Islamabad, Pakistan \\ Email: mushtaq.alvi@gmail.com

\section{Dr Muhammad Munir Kayani}

Assistant Professor, Department of Education, Faculty of Social Sciences, International Islamic University, Islamabad, Pakistan

Email: drmunirkayani@yahoo.com

\section{Dr Manzoor Hussain Arif}

Professor, Air University, College of Education

\author{
Doi:10.5901/mjss.2015.v6n5s1p35
}

\section{Abstract}

Bandura (1977) presented the social learning theory. It focused on propagation of a symbolic learning model where learning takes place by observing and experiencing things particularly in digitalized form. The students of today are exposed to a lot of things; they watch experience interact daily so their learning has become broadened by joining world communities and cyber space, sharing and affecting the world by their actions, ideas and beliefs. They are exposed to different contents which they may not have seen or observed. The objectives of the study were to find out the possibilities and prospects of symbolic learning use in universities. The students of social sciences from the twelve selected universities were the accessible population of the study. A nine item questionnaire was used to carry out this survey research. The data were analysed by using SPSS descriptive statistics and frequencies. The study explored the possibilities and prospects of using ICT as a tool for application of symbolic learning. It explored availability and access of the students at university level that can make one of the major component of symbolic learning. It is found that the universities are providing facilities to students and the students themselves have access and availability of information and communication technology. It was recommended to develop digital contents apart from bringing in the already developed contents to the country. The teachers need to be equipped by knowledge and use of ICT. Mobile phone may also be used as a device for learning.

Keywords: Information Communication Technology, Symbolic, Learning, Universities

\section{Introduction}

Bandura (1977) presented the social learning theory. It focused on propagation of a new set of models; live learning model, instruction learning model and symbolic learning model. Each of the models focuses on certain aspect of learning. Live learning model encompasses real life situation in which the learner is brought into direct contact with live situation to observe and see the things. The instruction model emphasizes on instruction set out for learners to perform some acts. The instructions are clear and direct which lead learner to the real life conditions. The symbolic learning model endeavours an assumed and a staged life situation in the forms of films, dramas and stage shows. It also focuses on interaction of human to different gadgets of technology like television, mobile phones and computer. The learning is a complex issue and by observing students motivation to have access and interaction with these modern gadgets one can easily forecast the future of teaching and learning as is argued by researchers.

Prince (2004) argued that students learn effectively when the activities had been developed on the basis of measurable learning outcomes to promote profound action, resulting in knowledge retention, conceptual understanding and engagement. The motivation plays very important role in boosting and developing the learning spirit of the students.

Clark (2004) defined learning as students' technique of adopting to and using stimuli in context of learning which later on he himself practices and produces. The observational learning considers observation as an important source for learning. The observation can be of two major kinds in this high tech world, direct observation and indirect observation. 
The first kind requires physical movement and observing things minutely and necessary for one to be present at the event while the second kind of observation can further be divided into symbolic and live observation. There are differences based on originality of the things like the first is manipulated, the other can be captured and presented from one angle while the other angles remain unobserved. The quality and expertise required for preparing a scene or event for digital contents depends highly on the person and the device used to prepare and capture. This digital media age reflects high social expectations, professional competence and extreme carefulness to integrate ICT in education because it is not just add-on teaching or learning but a medium of literacy and learning beyond traditional reading and writing. This is not an easy task even if the teachers and learners have skills to do so; therefore it needs to take advantage of action research to find practical implications relevant to social contexts.

The question how symbolic learning is associated with information and communication technology needs to be addressed. In the era of technology where everything depends on technology, learning has also been pillowed by it because the interaction of human beings with it is more frequent and continuous. It is a learning that takes place by observing and experiencing the things particularly in digitalized form. The students of today are exposed to a lot of things; they watch experience interact daily so their learning has become broadened. They are joining world communities and cyber space sharing and affecting the world by their actions, ideas and beliefs. They are not restricted to their own class teacher or subject teacher but they are exposed to different contents which they may not have seen or observed. They try to go deep down and find the information through digital media which provides them symbolic learning which have apparently great effects.

The world is growing rapidly into a global village and it has been energized by digital media. The term 'digital media' covers different sources that include internet and mobile phones. The students learn many things from them and cherish ideas and concepts; they are too busy in using these sources. They are helpful in curricular activities but they mostly prevent them from going to extracurricular activities. Physical exercise and socialization are two very significant areas of learning which play important role in building a stable and balanced personality. In the present world, students are keen to explore and experience different things particularly away from their own culture, tradition and society. The section of the society selected for this study is the university students because this is the powerful age period, a prime time and the most vulnerable duration of life. It is time that shapes the destiny of youth and future career and ideas are strongly built up. The need of the time is to explore the serious issues related to their developments, socially, mentally and physically.

\section{Objectives of the Study}

The study explored the possibilities and prospects of using ICT as a tool for application of symbolic learning. It explored availability and access of the students at university level that can make one of the major tools of symbolic learning.

\section{Research Questions}

Following were the research questions

1 What type of computers and internet connections are available at the university or at home?

2 Do the students have laptops?

3 Do the students have access to high speed internet connection

4 How long the university lab is available to the students?

5 How long students use computer daily?

6 Do the students have access to digital books and journals

\section{Significance of the Study}

The study is likely to be useful for students themselves, teachers of the university colleges and policy makers to develop and design a framework for implementation of ICT based teaching learning environment both in universities and colleges. It also has fruit for thoughts for educational administrators and university administration to raise their standard of the computer laboratory with high speed internet connection. It is also valuable for computer lab incharge for improvement in their infrastructure and management of it. 


\section{Research Methodology}

The population consisted of all the students of public and private universities in the province of Punjab and Islamabad Capital Territory. The students of social sciences from the twelve selected universities were the accessible population of the study. Two stage cluster sampling technique was used for this study. The first stage sampling was about universities selection from public and private sector. The second stage cluster was departments under Social Sciences umbrella particularly Education, Psychology. The respondents were selected randomly from these departments. Questionnaire was used to collect data from the respondents. Validity of the questionnaires was established from conducting pilot testing and by getting experts opinions. The reliability of the questionnaire was checked by Cronbach Alpha.The data was collected by multiple ways, firstly the researcher personally visited some of the universities to distribute the questionnaire and collected them back. Secondly, the researcher sent questionnaire to friends, acquaintance in other universities to distribute the questionnaire to the respondents in the respective departments of the universities and collected them back and returned back to the researcher.

\section{Literature Review}

Learning has different forms and formats. Symbolic learning basically envisaged learning through simulation or learning by using digital device to have a better concept of the things by watching them on screens. It includes television internet and mobile phone. The focus of the study is internet and mobile phone. Let's see how learning actually takes place in the modern world.

Harrison et al. (2002) criticized that a very little was developed and designed so far to meet and manage internet knowledge as one of the reliable and valid construct. There is need to examine potential effects of internet acceptance. It means that there is need of the time to maintain and develop such type of learning activities that could meet the chances and challenges of the coming year effectively and efficiently. The nation who will do it may surpass the other in world knowledge based economy

Crabtree (2003) surveyed university students and found that only (43\%) students had laptops showing a disparity but after ten years I think the ratio must have been increased so far. The students had portable computers, mobile phones, cameras and music players which proves ownership of one of the technology gadgets. A newer trend had been observed that states are going to prefer mobile phone technology in place of fixed networks particularly in rural areas. That is why there is almost all parts of the world are of mobile phone coverage. It has boosted the idea of learning through mobile especially in remote areas.

Leadbetter (2005) concluded that learning is being reorganized and restructured because it has become a personalized, individualized and learner based activity as new technologies had offered students oriented services. Now the learning had not been traditional only classroom based activity but a situated and collaborative learning practice that had enabled people to developed communication links across the world.

Shah et al (2005) concluded that media plays significant role in learner life but how can it be averted. He suggested that stopping media is almost impossible. This world is world of screens and computers which has shifted people attention toward electronics rather than traditional reading and writing if change is not adopted and modified as per requirement of the time than ICT would do it itself.

Lippert and Forman (2005) suggested technology model does have a value that could raise serious issues like technology mapping, technology adoptions and their parsimony and generality. Supplementary theories and models are needed to incorporate and inculcate social change by digitalization. Social learning theory anticipated its width and breadth for technology acceptance. Theoretically it proposed different learning aspects that had potential to enhance digitalized curriculum and learning by using high technology.

Cheung and Huang (2005) stated that the Internet has become one of the major source for integration in school and college education in the world. The teachers and students are encouraged to communicate to interact via internet and mobile phones. The use of hard copy notes might be avoided and material could be uploaded for students. The instructions given on net are easily accessible and manageable because they pass most of their time on net and they have their peers and groups to share their ideas and beliefs. Physical travelling, displacement of oneself, carrying out load of books, boosting traffic problems daily and suffering from daily travel fatigues can be avoided by using ICT mode of learning.

Bickham, et al (2006) explored television viewership, time they spent on it, television contents and peer integration along with its effect on them. In conclusive remarks, it was stated that more the students watch TV less they have time for their friends. Resultantly they have poor peer relationship and suffered social isolation and anxiety disorders. They are 
socially bent toward antisocial behavior, agoraphobia, aggression and gang participation.

Barak (2006) stated that technology embedded devices are major sources of learning as it could be observed in photocopiers and television, both performed human functions themselves as they keep a user manual with them. Their durability is also extended as new software packages help us to last a longer time. People can store, arrange and preserve their valuable documents in save and they can be retrievable when they are needed.

Taylor, Sharples and Vavoula (2006) explaining mobile learning stated that it is imperative to distinguish the basic characteristics of mobile learning and other type of learning process. A vivid distinction is the assumption of learning while at move which is a continuous process. The mobile learner collects and gathers ideas, information from one location and applies or replicates it in another place. Time does not affect them because learning can takes place at any time and any place, he actually revisits knowledge putting different context, making generalization, concluding results and modifying them as per requirement of the situation and making himself as lifelong learner. The theory of mobile learning has to embrace a large amount of learning that happens outside classroom and many other formal learning places because people started to construct their actions as structured one depending on educational activities.

Gemmell, Bell, \& Lueder (2006) proclaimed that mobile phone learning stipulated many serious issues such as ethics, privacy and ownerships. The mobile phone is a helpful device to organize, allow and reflect upon the recorded pictures, sounds and lectures after the classroom. For lifelong learning and short memory students it would be a powerful device to keep and check record and a learning aid. The parents and teachers may also check their activities and it would become an extension of school activity while they are at leisure.

Sheikh (2007) made analysis of role of television and social change in the country. It identified the nature of television viewership as compare to other medium of mass communication. It finds changes in other social elements as culinary practices, their attire, house construction, architectures, house decoration, music traditions, social customs, and celebration of festivals, education system, clans and family system concluding that change occurs in all sphere of life.

Potosky (2007) confirmed that computer and internet knowledge has directed the way and pattern of life of the learners in day to day life. He did not mention which way and life pattern were directed and how they were directed. It is true in the European context where mobile learning and technology has taken deep roots and scholars are searching out for the contents of learning which could be delivered to the students through mobiles contents.

Vavoula (2009) believed that learning is a dynamic activity which could not be separated from daily routine actions. The questions whether we can classify learning and non-learning activities which are a very difficult because all type of activities involve some or the other type of learning as all activities are interwoven. Learning takes place when human wants to satisfy their goals and objective either they are externally set or generated by one self. The process of generating and regenerating continues as learning broadens by forming new target, goals and expeditions. The difference between class room learning and mobile learning is that the first is linked with teachers, course contents while mobile learning is associated with many resources like guides, technologies, plants, animals and buildings including teachers and books.

Sharples et al, (2012) explained that tagging devices on mobile phone would affect privacy law but they are more useful for parents and teachers. Considering its benefits it is not only another type of learning but also another type of complete learning package as before emergence of computer technology, the mass print era emphases on text books as medium of instruction, today it is needed to re-conceptualize the construction of knowledge as processing, modelling and interacting process depending upon conversational context through mobile technology.

Tarasowa (2013) stated that technology has potential and possibilities to replace the traditional pattern of learning because the world is rapidly changing and cyber interaction has opened up diverse direction for learner as well as teachers. It means that current researches in developing countries need to focus on exploring the possibilities of using ICT gadgets as learning tools in place of traditional classroom restricted learning environment.

Ally and Petro (2014) emphasising on future of mobile phone claimed the next decade will change the learning environment because most of the information is being transferred to a small gadget called mobile phone which has space and speed like computers but they are easily portable and moveable. This device will help to build communities and networks of social learning.

Gerstein (2013) confirmed that the increasing availability of the online and open sources are becoming affordable and easily manageable for the learner. The problem lies in how to develop contents and text for the purpose of teaching through mobile phone considering the learners culture, values and local context because the available material is most of the time not very much relevant to the user context

Hassan, Hamdan \& Al-Sadi (2012) focused on the process of mobile content preparation because these contents are flammable once they are published they spread all over the world, leaving aside the context that is mentioned earlier. In contents development one has to be very vigilant and care full because they may have biased material with many other 
shortcomings and weaknesses.

\section{Current Scenario of ICT in Pakistan}

There is no doubt that Pakistan is facing many challenges. It needs to confront these challenges boldly and sagaciously. It has talented youth among its population. Pakistan is situated in south Asia, one of the big users of internet and mobile phone. The statistics says that Asia uses $44.8 \%$ of the total internet use in the world which tell us that how big the scope and market of internet is in Asia.

Pakistan is a developing county, having many internal issues like terrorism, literacy, health, rule of law and unemployment and external pressures by big powers to deliver more. It is one of the least literate countries in the Asian region having literacy ratio of about $50 \%$ that means $6.2 \%$ of the world population lives in Pakistan. It is fourth largest contributor to the non-literate population which can be estimated that by next year 2016, the county's non literate population will cross 55 million, even then they are one of the main internet users in the world. In spite of all these factors, the internet mobile use is rapidly increasing and about more than $50 \%$ of the population, including women, have mobile phones.

In Asian countries Pakistan stands out prominently as it is heading Malaysia and Thailand in internet use, the following tables shows the exact figures.

Table 1: Top Asian Internet user Countries 2012

\begin{tabular}{|c|c|c|}
\hline 1 & China & 513.0 \\
\hline 2 & India & 121.0 \\
\hline 3 & Japan & 101.2 \\
\hline 4 & Indonesia & 55.0 \\
\hline 5 & S.Korea & 40.3 \\
\hline 6 & Vietnam & 30.5 \\
\hline 7 & Philippine & 29.7 \\
\hline 8 & Pakistan & 29.1 \\
\hline 9 & Thailand & 18.3 \\
\hline 10 & Malaysia & 17.7 \\
\hline
\end{tabular}

The table shows that Pakistan is among the top ten countries of Asia in using internet more than others. The Asian Tribune reports that with the rapid growth of cell phone use and continuous growing of internet adoption with high internet connections in Pakistan, has raised chances of access and availability to information and communication technologies (ICTs). The broadband internet users had crossed the 1.5 million mark which is a significant growth in telecom industry. Internationally Pakistan was ranked and rated among top ten countries who registered themselves as high growth rate in broad band internet penetration. A booming telecom sector recorded as $46.2 \%$ growth rate of subscribers clinching fourth position in the ranking list, supported by fifty (50) internet service providers and ten (10) broad band companies providing services across the country.

World Bank (2010) reported Pakistan one of the countries rapidly increasing access for financial services apart from other countries of the world in using smart bank cards and cell phone networks. Cell phone penetration has rapidly increased removing the barriers of gender discrimination, half of the population including males and females, urban and rural areas do have an access to cell phone.

\section{Analysis of Basic Facilities}

At this stage, the data was collected in view of finding of the availability of ICT resources at campuses of the universities and off campuses. The basic infrastructure for full utilization of ICT facilities and how student take these facilities and ICT contents was major focus at the stage. There are nine tables show attention stage of symbolic learning model. The data is presented in form of tables and graphs. 
Table 1: PC's Available at University Campus

\begin{tabular}{cccccc}
\hline PIII & PIV & Dual Core & I core 1or More & Not Available & Total \\
\hline 46 & 463 & 158 & 25 & 28 & 720 \\
$(6.4 \%)$ & $(64.3 \%)$ & $(21.9 \%)$ & $(3.5 \%)$ & $(3.9 \%)$ & \\
\hline
\end{tabular}

Table 1 shows a large majority of respondents (64.3\%) reported that they had PIV available at the university while a reasonable number (21.9\%) respondent marked that they had dual core in campus, whereas $6.4 \%$ marked that they had PIII and $3.9 \%$ claimed that there was no computer available for them in the university.

Table 2: PC available at Hostel or Home

\begin{tabular}{cccccc}
\hline PIII & PIV & Dual Core & I core 1or More & Not Available & Total \\
\hline 23 & 421 & 196 & 26 & 54 & 720 \\
$(3.2 \%)$ & $(58.5 \%)$ & $(27.2 \%)$ & $(3.6 \%)$ & $(7.5 \%)$ & $(100 \%)$ \\
\hline
\end{tabular}

The table no 2 showed that (58.5 \%) have PIV at hostel or home while (27.2 \%) had dual core, (7.5\%) had I core 1 or more while (3.2\%) had PIII, whereas (7.5\%) possessed no computers at home or hostel.

Table 3: Students Having Type of Laptops

\begin{tabular}{|c|c|c|c|c|c|}
\hline PIII & PIV & Dual Core & I core 1or More & Not Available & Total \\
\hline $\begin{array}{c}22 \\
(3.1 \%)\end{array}$ & $\begin{array}{c}124 \\
(17.2 \%)\end{array}$ & $\begin{array}{c}389 \\
(54.0 \%)\end{array}$ & $\begin{array}{c}70 \\
(10.4 \%)\end{array}$ & $\begin{array}{c}110 \\
(15.3 \%)\end{array}$ & $\begin{array}{c}720 \\
(100 \%)\end{array}$ \\
\hline
\end{tabular}

The statistics of above table 3 show that (54.0\%) students had dual core laptops, (17.2 \%) had PIV laptops. A small number of respondents had I core 1 or more laptops. (15.3\%) respondents did not have laptops with them. Even though the government had distributed many laptops but perhaps they had gone to only pure sciences subject students or high achievers.

Table 4: Status of computer lab in the university

\begin{tabular}{ccccc}
\hline Well Equipped & Not Equipped & Badly Managed & Not Available & Total \\
\hline 45 & 441 & 1972 & 62 & 720 \\
$(6.3 \%)$ & $(61.3 \%)$ & $(23.9 \%)$ & $(8.6 \%)$ & $(100 \%)$ \\
\hline
\end{tabular}

Table 4 show the status of computer labs. (61.3\%) students claimed that the university lab was not adequately equipped and $(23.9 \%)$ believed that it was badly managed. The statistics show that the universities pay inadequate attention to the labs for social sciences students. A small percentage of (6.3\%) said that their lab was well equipped while (8.6\%) claimed that there was no lab facility at university.

Table 5: Availability of net connection at university

\begin{tabular}{cccccc}
\hline Below 512 & $\mathbf{5 1 2}$ & 1Mb & 2Mb or More & Any other & Total \\
\hline 94 & 78 & 164 & 295 & 89 & 720 \\
$(13.1 \%)$ & $(10.8 \%)$ & $(22.8 \%)$ & $(41.0 \%)$ & $(12.4 \%)$ & $100 \%)$ \\
\hline
\end{tabular}

Table 5 indicates that (40.0\%) claimed that they had $2 \mathrm{Mb}$ speed connection at university while $(22.8 \%)$ said they had $1 \mathrm{Mb}$ connection speed at university campus. Other (13.1\%) said they had below $512 \mathrm{~Kb}$ connections at university while $(10.8 \%)$ said they had $512 \mathrm{~Kb}$ net speed at university. Another (12.4\%) said they had some other speed at the university campus.

Table 6: Internet Connection At Home

\begin{tabular}{cccccc}
\hline Below 512 & $\mathbf{5 1 2}$ & $\mathbf{1 M b}$ & 2Mb or More & Any other & Total \\
\hline 22 & 113 & 245 & 269 & 71 & 720 \\
$(3.1 \%)$ & $(15.7 \%)$ & $(34.0 \%)$ & $(37.4 \%)$ & $(9.9 \%)$ & $100 \%)$ \\
\hline
\end{tabular}


Table 6 shows that $(37.4 \%)$ of students had access to $2 \mathrm{Mb}$ speed connection at home, $(34.0 \%)$ had $1 \mathrm{Mb}$ net connection speed at home where as (15.7\%) had $512 \mathrm{~Kb}$ and (3.1\%) had below $512 \mathrm{~Kb}$ net connection speed at home. Another (9.9\%) had any other speed.

Table 7: Availability of Lab for Students Use in University

\begin{tabular}{cccccc}
\hline $\mathbf{8 - 2} \mathbf{~ p m}$ & $\mathbf{9 - 4} \mathbf{p m}$ & $\mathbf{9 - 5} \mathbf{~ p m}$ & $\mathbf{9 - 1 0} \mathrm{Pm}$ & Any other & Total \\
\hline 137 & 195 & 231 & 45 & 112 & 720 \\
$(19.0 \%)$ & $(27.1 \%)$ & $(32.1 \%)$ & $(6.3 \%)$ & $(15.6 \%)$ & $(100 \%)$ \\
\hline
\end{tabular}

Table 7 shows that (32.1\%) believed that lab was opened from 9-5 O' clock while $(27.1 \%)$ considered that it was opened from 9-4 O' clock, while (19.0\%) believed it was opened from 8-2 O'clock while (6.3\%) believed there lab in the university remained opened from $9 \mathrm{am}$ to $10 \mathrm{pm}$. It was found that the computer lab timing were short and they need to be extended to 9-10 slot for students and teachers convenience.

Table 8: Daily uses of computers by the respondents in terms of hours

\begin{tabular}{cccccc}
\hline Less than 1 hrs & $1-2 \mathrm{hrs}$ & $2-4 \mathrm{hrs}$ & $4-6 \mathrm{hrs}$ & More than $6 \mathrm{hrs}$ & Total \\
139 & 210 & 258 & 48 & 65 & 720 \\
$(19.3 \%)$ & $(29.2 \%)$ & $(35.8 \%)$ & $(6.7 \%)$ & $(9.0 \%)$ & $(100 \%)$ \\
\hline
\end{tabular}

Table 8 shows that (35.8\%) students used computer for 2- 4 hours while $(29.2 \%)$ used it for 1-2 hours daily while (19.3 $\%)$ used it less than 1 hour but (9.0\%) used for more than 6 hours and (6.7 \%) use 4-6 hours daily. This statistics shows that they spent quite a lot of time in using computer ranging from an hour to more than 6 hours a day.

Table 9: Accesses to Digital Books

\begin{tabular}{cccc}
\hline Yes & No & Do not Know & Total \\
\hline 565 & 147 & 8 & 720 \\
$(78.5 \%)$ & $(20.4 \%)$ & $(1.1 \%)$ & $(100 \%)$ \\
\hline
\end{tabular}

Table 9 displays the results of access to digital books at university campus ( $78.5 \%)$ confirmed that they had access to digital books while $(20.4 \%)$ admitted that they had no access to digital books. Only (1.1\%) did not know about it. The percentage shows that majority of students had access to digital library at university campus.

\section{Findings}

1. It is established that a large majority of the respondents (64.3\%) and (58.5\%) had access to personal computer PIV at university and at home respectively.

2. The data shows that $54.0 \%$ respondents had dual core laptop while $(17.2 \%)$ which makes that $(71.2 \%)$ possess laptops

3. The tables 5 and 6 presented that almost 95\% students have access to internet at university and at home, although the speed of the net varies from university to university and individual to individuals.

4. The table 7 depicted that university lab is available for the students for all the day although the timing varies from university to university

5. The table 8 displayed that $65 \%$ students use computers for 2 to 4 hours daily which presented that they used computer for quite a reasonable time during a day.

6. The table 9 painted another positive picture the (78.5\%) confirmed that they had access to digital books at university which also is encouraging for using ICT as a powerful source of learning/

\section{Discussion}

Enhancing Bandura (1977) symbolic learning with information and communication technology requires first the access 
and availability of ICT. The present study has explored the possibilities and prospects of using it as a tool for teaching and learning purposes as earlier different scholar supported it and claimed as Bhattacharya and Sharma, (2007) found that ICT helps to create digital resources apart from course material at any place and anytime. Cholin (2005) believed that these facilities permit the teacher and learner to share their scholarly material and it also prevents them from duplication. Kozma (2005) confirmed that ICT prepares a work force for tomorrow information and global economic society. The above mentioned six points confirmed that the availability and access of ICT is available to the students but it is imperative to develop such a material for imparting to the young learners through media and technology. If the nation wants to compete and excel in all areas of modern gadgets they must try to incorporate technology and reorganised education system by ICT. For this purpose they need to develop and design modules, course contents and activities depending on digital formats which require the access and availability of basic infrastructure among the educational institutions.

Roberts (2013) discussing the access and availability of the ICT concluded that there are so many things that are changing day by day like applications, software and new program that keep one busy in updating himself and his students all the time. The need of the day is to promote consistency and availability of the latest equipment and technology to higher education institution for improving their infrastructures and full implementation of the ICT based learning environment

Stoerger (2013) argued that mobile phone can replace the books and note books because they have so many characteristics, convenience, easy, simple and quick sources of information and communication breaking the geographical boundaries and removing the distances by bringing people and communities closer and closer. The knowledge hegemony will shatter down soon

\section{Conclusion}

The data and statistics proved that the university students do have access and availability of information and communication technology. There is a possibility of enhancement of curriculum and method of teaching by using ICT. Although it varies from place to place and university to university but the need of the time is to develop digitalised contents and curriculum to engage the students and teachers for improved and better market. There is no doubt that the universities need to improve their infrastructure which forms personal computers, internet speed and the timing of the computer labs so that the learners and teachers take more benefits of it. The study highlighted the social sciences sector among universities, it is possible that the other discipline may have different prospects but as far as social sciences are concerned they are much ignored and not recognised as preferred subjects.

\section{References}

Ally, M. \& Prieto-Blázquez, J. (2014). What is the future of mobile learning in education? Mobile Learning Applications in Higher Education [Special Section]. Revista de Universidad ySociedad del Conocimiento (RUSC). Vol. 11(1) pp. 142-151. doi http://dx.doi.org/10.7238/rusc.v11i1.2033

Bandura, A. (1977). Social Learning Theory. Englewood Cliffs, NJ USA: Prentice Hall

Barak, M. (2006). Instructional principles for fostering learning with ICT: Teachers' perspectives as learners and instructors. Education and Information Technologies, 11, 121-135.

Bhattacharya, I. \& Sharma, K. (2007), 'India in the knowledge economy - an electronic paradigm', International Journal of Educational Management Vol. 21 No. 6, pp. 543-568.

Bickham, D. S., Wright, J. C., \& Huston, A. C. (2001). Attention, Comprehension, And The Educational Influences Of Television. In D. G. Singer \& J. L. Singer (Eds.), Handbook of children and the media (pp. 101-119). Thousand Oaks, CA: Sage.

Cheung, W. \& Huang, W. (2005). Proposing A Framework to Assess Internet Usage in University Education: An Empirical Investigation From A Student's Perspective. British Journal of Educational Technology, 36(2), 237-253.

Cholin, V. S. (2005). 'Study of the application of information technology for effective access to resources in Indian university libraries', The International Information \& Library Review 37(3), 189-197.

Clark, Don, (2004). Learning Styles: Or, how we go from the unknown to the known. Available at: http://www.nwlink.com/ donclark/ hrd/learning/styles.html.

Crabtree, J., Nathan, M. and Roberts, S. (2003). MobileUK: Mobile phones and everyday life.London: The Work Foundation.

Gemmell, J.,Bell G., and Lueder,R. (2006). MyLifeBits: a personal database for everything, Communications of the ACM, vol. 49(1).

Gerstein, J. (2013). Team and community building using mobile devices. In Z. L. Berge \& L. Y. Muilenburg (Eds.), Handbook of mobile learning. New York, NY: Routledge.

Hassan, M., Hamdan, Z., \& Al-Sadi, J. (2012). A new mobile learning content design process. International Journal of Academic Research, 4(1), 23-28. 
Harrison, C. et al. (2002). ImpaCT2: The Impact of Information and Communication Technologies on Pupil Learning and Attainment. Coventry: Becta.

Kozma, R. (2005). 'National Policies That Connect ICT-Based Education Reform To Economic And Social Development', Human Technology Volume 1 (2), October 2005, 117-156.

Leadbetter, J.(2005). Activity theory as a Conceptual Framework and Analytical Tool within the Practice of Educational Psychology, Educational and Child Psychology, 22(1) ISSN: 0267-1611.

Lippert, S.K. \& Forman, H. (2005). Utilization of Information Technology: Examining Cognitive and Experiential Factors of Post-Adoption Behavior. IEEE Transactions of Engineering Management, 52(3), 363-381.RC (National Research Council). 1999.Effectivness in Education, How People Learn. Washington, DC: National Academy Press.

Prince, M., (2004). Does Active Learning Work? A Review of the Research. Journal of Engineering Education, v. 93, p. $223-231$.

Potosky, D. (2007). The Internet Knowledge (iKnow) Measure. Computers in Human Behavior, 23(6), 2760-2777.

Roberts, J. B. (2013). Accessibility in M-Learning: Ensuring equal access. In Z. L. Berge \& L. Y. Muilenburg (Eds.), Handbook of mobile learning. New York, NY: Routledge.

Shah. D.V., Cho, J., Eveland, W.P.Jr. \& Kwak, N. (2005). Information and Expression in a Digital Age: Modeing Internet Effects on Civic Participation. Communication Research, 32(5), 531-565.

Sharples, M., Ainsworth, S., Beale, R., FitzGerald, E., Vavoula, G. (2012). Connect: Exploit the power of personal devices to enhance learning. System Upgrade: Realising the vision for UK education. A report from the ESRC/EPSRC Technology Enhanced Learning Research Programme. Director: Richard Noss, London Knowledge Lab.

Sheikh, M. A. (2007). Satellite Television and Social Change in Pakistan: A case study of rural Sindh. Karachi: Orient Books Publishing House.

Stoerger, S. (2013). Becoming a digital nomad: Transforming learning through mobile devices. In Z. L. Berge \& L. Y. Muilenburg (Eds.), Handbook of mobile learning. New York, NY: Routledge.

Tarasowa, D., Khalili, A., Auer, Sö. \& Unbehauen, Jö. (2013). CrowdLearn: Crowd-sourcing the Creation of Highly-structured E-Learning Content. 5th International Conference on Computer Supported Education (CSEDU 2013) (p./pp. 33-42), .

Taylor, J., Sharples, M., O'Malley, C., Vavoula, G., \& Waycott, J. (2006). Towards a Task Model for Mobile Learning:a Dialectical Approach. Accepted for publication in International Journal of Learning Technology.

Vavoula, G. (2009). Issues and requirements for mobile learning research. In Vavoula, G., Pachler, N., and Kukulska-Hulme, A. (Eds.), Researching Mobile Learning: Frameworks, methods and research designs. Oxford: Peter Lang Publishing Group. 